\title{
Nutritional Education as an Indicative Element of Lifestyle
}

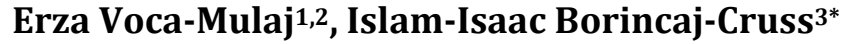 \\ ${ }^{1}$ Faculty of Dentistry, University of Prishtina, Prishtine, Kosovo \\ ${ }^{2}$ Department of Nutrition, University of FAMA, Prishtine, Kosovo \\ ${ }^{3}$ Faculty of Arts and Social Science, International University of Sarajevo, Sarajevo, Bosnia and Herzegovina \\ Email: arteda.dent@gmail.com, *bosia@ius.edu.ba
}

Received 10 April 2016; accepted 13 June 2016; published 16 June 2016

Copyright (C) 2016 by authors and Scientific Research Publishing Inc.

This work is licensed under the Creative Commons Attribution International License (CC BY). http://creativecommons.org/licenses/by/4.0/

\section{c) (i) Open Access}

\section{Abstract}

This is a theoretical analysis that aims to disassemble the connection between nutritional education and lifestyle. Literature used in this theoretical analysis is various reports of the World Health Organization and different national and international sources. Nutritional education can be defined as any combination of teaching methods designed to facilitate the adoption of voluntary food choices and other types of food with the addition that this includes appropriate behavior meals that are important for the health and welfare of the individual, community or even a certain population. Social influences on food intake refer to the impact that one or more persons have on the eating behavior of others, either direct or indirect, either conscious or subconscious. Even when eating alone, food choice is influenced by social factors because attitudes and habits develop through the interaction with others. As the need for nutrition education, change is the most important. Food preferences pose a problem with the people in the selection of food. Most people do not have conditions to ensure healthy food which suits meal-times. Some others see nutritious instructions as boring, unpleasant and inappropriate. Lack of time, often does not to dedicate relevance of food choices, especially among the educated young people. Practical aspects such as cost, preparation and poor availability of time due to work are common barriers to the recommended changes. Lack of knowledge about the importance of healthy eating is not perceived by consumers as the main barrier to changing diets, although it is quite important.

\section{Keywords}

Nutritional Education, Lifestyle, Health, Dangerous Diseases, Malnutrition

\footnotetext{
${ }^{*}$ Corresponding author.
} 


\section{Introduction}

The World Health Organization has stated that nutrition is an input and basis for health and development. Proper nutrition makes people stronger and more productive. Eating healthy food enables a stronger immune system, less illness and better health.

Proper nutrition and health are an essential key to improving the quality of life [1]. Interrelationships between health, diet and disease prevention are some phenomena which every day more and more are becoming clearer and aware of different people around the world.

Nutritional education, promotion of appropriate eating behaviors and lifestyles are moving towards to have a significant attention either through social networks, media or billboards. Consequently, nutritional education should be included in the dissemination of information in order for it to be more effective. In a broader sense, nutritional education can be defined as "any combination of teaching methods designed to facilitate the adoption of voluntary food choices and other types of food with the addition that includes appropriate behavior meals that are important for a health and welfare to the person, community or even a certain population" [2].

Social influences on food intake refer to the impact that one or more persons have on the eating behavior of others, either direct or indirect, either conscious or subconscious. Even when eating alone, food choice is influenced by social factors because attitudes and habits develop through the interaction with others [1].

Research has shown that we eat more with our friends and family than when we eat alone and the quantity of food increases as the number of fellow diners grows [2].

The relationship between low socio-economic status and poor health is complicated and is influenced by gender, age, culture, environment, social and community networks, individual lifestyle factors and health behaviours. Population studies show that there are clear differences in social classes with regard to food and nutrient intakes. Low-income groups in particular, have a greater tendency to consume unbalanced diets and have low intakes of fruit and vegetables [3].

The relationship between low socio-economic status and poor health is complicated and is influenced by gender, age, culture, environment, social and community networks, individual lifestyle factors and health behaviours [4].

Population studies show that there are clear differences in social classes with regard to food and nutrient intakes. Low-income groups in particular, have a greater tendency to consume unbalanced diets and have low intakes of fruit and vegetables [3].

This leads to both under-nutrition (micronutrients deficiency) and over-nutrition (energy overconsumption resulting in overweight and obesity) within the members of a community, depending on the age group, gender and level of deprivation. The disadvantaged people also develop chronic diseases at an earlier age compared with higher socio-economic groups, usually identified by educational and occupational levels.

Low-income groups who find it difficult to achieve a balanced healthy diet, are often referred to as experiencing food poverty or food insecurity [5]. There are many aspects to food poverty but three of the main barriers to eating a balanced healthy diet include cost, accessibility and knowledge [6]. These factors have led to the development of areas known as food deserts. A reliance on energy-rich, nutrient-poor foods is a consequence of lack of money to buy wholesome foods. The price premium on healthy foods also appears to be greater in lowincome areas. Moreover, a lack of proper cooking facilities at home increases the need to eat convenience or take-away food that has a potentially higher energy density.

Living on a low income can also present logistical obstacles to eat well, such a lack of transportation. Public transport is not a viable solution for many, particularly those with young children or mobility difficulties. Finally, a lack of knowledge or too much conflicting information on diet and health, lack of motivation and the loss of cooking skills can inhibit buying and preparing meals from basic ingredients. Experimenting with cooking is a luxury that low-income groups can ill-afford.

Education level and income determine food choices and behaviours that can ultimately lead to diet-related diseases. The origins of many of the problems faced by people on low incomes emphasises the need for a multidisciplinary approach to targeting social needs and improving health inequalities.

Therefore, nutrition education should be viewed in a broader context that includes other factors that affect food choices and lifestyles; environments where people work, act, learn and play have a fundamental impact on diet and to their physical activity [2].

Practical aspects such as cost, preparation and poor availability of time due to work are common barriers to the recommended changes. Lack of knowledge about the importance of healthy eating is not perceived by con- 
sumers as the main barrier to changing diets, although it is quite important [8].

Three of the ten leading causes of death in the US are directly related to nutrition. These diseases are coronary heart disease, cancer, and diabetes mellitus [9]. The prevalence of unbalanced diet and lifestyle has resulted wit obesity and other dangerous diseases [1].

Lacks of nutritional education, malnutrition as a result of socioeconomic basic conditions are sufficient to increase the risk of various diseases in humans. Based on this, we can say that nutritional education or the food manner is associated with a lifestyle that makes a person and under the conditions, the person can progress or stagnate in this regard [10]. According to the World Health Organization, all forms of malnutrition are directly related to the number of deaths, mortality, and economic costs rising [1]. However, lack of nutritional education sends people in malnutrition, which is defined as poor nutrition as a result of the scarcity of food, the application of an unbalanced diet, or excessive use of food. Also, there are about a billion people worldwide who have a lack of nutritional education and malnutrition as the results of these aspects:

Their life and incomes are insufficient to ensure the food and that comes in paralysis of nutrition education, then the lack of skills to prepare food and adequate products. But it is worth noting that improving the living cost in a natural manner, also provides nutrition education of the people [11]. Without considering developing countries and lifestyle that makes people, nutritional education should be comprehensive but being balanced with their lifestyle because it is more than necessary for both sides [12]. Because the lack of nutritional education is not only in under developed countries, but also in industrialized countries and has a connection with the person's education and lifestyle they do. Most of the victims are the people who apply a diet to lose weight quickly [7].

Many pregnant women, infants and children are also victims because their nutritional needs are relatively high. Illness, injury, alcohol and drug abuse can hinder digestion and metabolism of food [1]. Psychologists have described two types of knowledge about nutritional educations in a person's life: The first is the declarative knowledge that has to do with recognizing things or process, e.g.: Someone may know that vitamins are essential to one's diet; or too fat are not beneficial to one's diet [9]. Procedural knowledge is concerned with the practical application of declarative knowledge as e.g. preparation of certain foods. So obviously feeding behavior involving these two kinds of knowledge [13].

Regarding the question of nutritional knowledge as applied in everyday life, the answer to this depends on the person himself, for example, an old lady may need educational feeder, as well a child in elementary school may need educational feeder [4].

The value of food is related to the person's values and experiences pleasure from food or the need that complements, and so people make the difference in where someone consumes food a certain food and another not, where someone considers unhealthy eating a certain food and someone else uses it to supplement food hunger and not concerned about his/here health at all [2].

Finally, the creation of an environment that enables healthy choices and sustainable living are especially important for those who are faced with inadequate facilities or unaffordable recreational and unsafe environments for walking, jogging or cycling. Alliances between government, local authorities and public health authorities will need to be unified to create an environment that facilitates lifestyle changes and complements nutrition education messages [6]. It is noteworthy that saving changes in health behavior. It is more difficult and requires motivation, ability and behavior and social support [12].

\section{Some Recommendations on Nutrition, Diet and Health}

Foods that prevent breast cancer as a generalized disease, according to a study in eight women risk of this disease. Experts give advice on what to eat to reduce the development of breast cancer. Various studies show that the risk of some cancers affected by diets, especially if you do not eat fruits and vegetables enough and abuse with narcotic and psychoactive substances. Experts remain faithful to Mediterranean diet with fresh fruits and vegetables, fish, olive oil, which reduces the risk of breast cancer, especially in women after menopause. Always referring to the study, $9 \%$ of cancer could be prevented by changes to food regime.

\subsection{What Should Be Eating More}

You should eat at least five portions of fruit and vegetables, which are rich in antioxidants that prevent the oxidation process $\left(\mathrm{O}_{2}\right.$ molecules merge with other chemicals and form cancerous cells). They are also rich in fiber 
that prevents the risk of cancer. Green vegetables (dark) such as spinach and cabbage are rich in Vitamin B which enhances DNA and reduces the risk of cancer, even vegetables like broccoli and Brussels sprouts, cauliflower, green salads are also a good source to prevent the formation of cancer cells.

\subsection{What Should Be Eating Less}

Red Meat-his grease-saturated associated with breast cancer risk in the postmenopausal period and slim chances of survival after diagnosis with cancer. Eat 70 - 90 grams per day and avoid meat fried or grilled. Sweets, cookies, pastries. Those contain hidden fats and hydrogenated which raise cholesterol levels. Sugar increases the glucose level and insulin concentration known as much risk for breast cancer. Even processed foods with some of the products mentioned above are believed to be cancerous.

\subsection{The Secret of a Healthy Diet}

Having a perfect body and an excellent shape is difficult. Diets do not always have the expected effect and are very uncomfortable. But there is a special way to lose weight through a healthy diet.

a) Count calories

b) Cut down on sugar and fat

c) Avoid sugary drinks and alcohol

People who live in the area around the Mediterranean Sea have been found to have a lower risk of heart disease.

Research studies show that when people in other parts of the world eat a diet similar to that eaten in Mediterranean countries, they reduce their risk of heart disease.

The Mediterranean diet contains large amounts of fruit, vegetables, and vegetarian proteins, moderate amounts of whole grains, and small amounts of red meat. Regular use of fish, olive oil, and nuts makes this diet higher in fat than the classic "heart healthy diet", but the fat is mostly unsaturated, which can be good for the heart. The pyramid to the left (Figure 1) and the chart (Table 1) describe the types and amounts of foods found

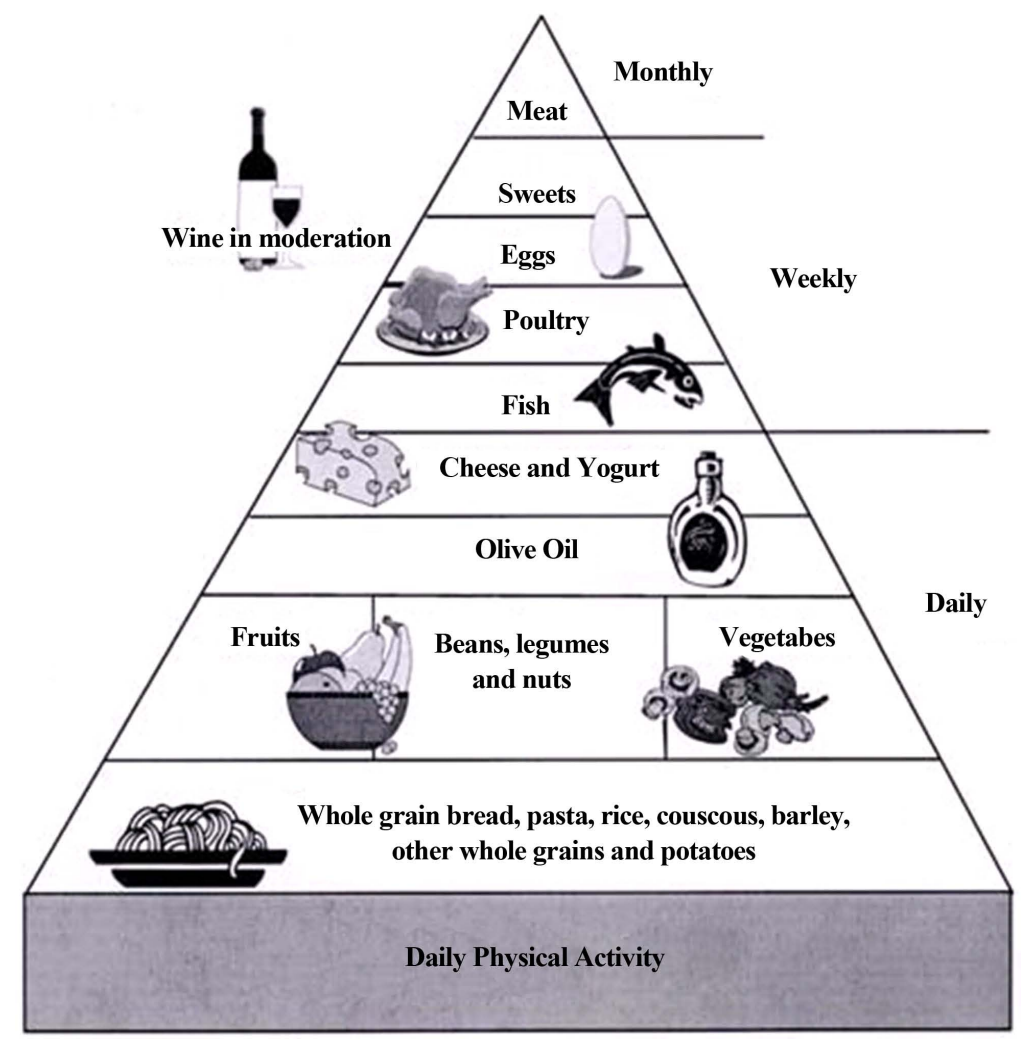

Figure 1. Mediterranean diet foodpyramid. 
Table 1. Mediterranean diet-food guide.

\begin{tabular}{|c|c|}
\hline Food groups & Serving sizes, examples, and notes \\
\hline $\begin{array}{l}\text { Non-starchy vegetables } \\
4 \text { - } 8 \text { servings per day }\end{array}$ & $\begin{array}{l}\text { 1/2 cup cooked vegetables } 1 \text { cup raw vegetables } \\
\text { - } \quad \text { Non-starchy vegetables include all vegetables except: potatoes, corn, peas and winter squash. }\end{array}$ \\
\hline & $\begin{array}{l}\text { One small fresh fruit } \\
1 / 4 \text { cup dried fruit }\end{array}$ \\
\hline $\begin{array}{l}\text { Fruit } \\
2 \text { - } 4 \text { servings per day }\end{array}$ & $\begin{array}{l}\text { - } \quad \text { Whole fruits are preferred because of the fiber and other nutrients they contain. } \\
\text { Fruits canned in light syrup or their own juice, and frozen fruit with little or no added sugar are also } \\
\text { good choices. } \\
\text { Use only small amounts of fruit juice ( } 8 \text { oz per day or less), since even unsweetened juices can } \\
\text { contain as much sugar as regular soda. }\end{array}$ \\
\hline $\begin{array}{l}\text { Low-fat dairy products } \\
1 \text { - } 3 \text { servings per day }\end{array}$ & $\begin{array}{l}1 \text { cup of skim milk or light yogurt } 1 \mathrm{oz} \text { of low-fat cheese } \\
\text { - } \quad \text { Soy milk, soy yogurt, and soy cheese can take the place of dairy products. } \\
\text { If servings of dairy or fortified soy are less than } 2 \text { per day, a calcium and vitamin D supplement is } \\
\text { advised. }\end{array}$ \\
\hline $\begin{array}{l}\text { Whole grains and } \\
\text { starchy vegetables }\end{array}$ & $\begin{array}{ll}1 \text { slice whole wheat bread } & 1 / 2 \text { cup potatoes, corn, peas or winter squash } \\
1 / 2 \text { large whole grain bun } & 1 \text { small whole grain roll } \\
6 \text {-inch whole wheat pita } & 6 \text { whole grain crackers } \\
1 / 2 \text { cup cooked whole grain cereal } & \\
1 / 2 \text { cup cooked whole wheat pasta, brown rice, or barley }\end{array}$ \\
\hline 4 - 6 servings per day & $\begin{array}{l}\text { Whole grains are high in fiber and have less effect on blood sugar and triglyceride levels than } \\
\text { refined, processed grains like white bread and pasta. } \\
\text { Whole grains also keep the stomach full longer, making it easier to control hunger. }\end{array}$ \\
\hline & $\begin{array}{l}2 \text { Tbsp. Sunflower or sesame seeds } 1 \text { Tbsp. Peanut butter } 7 \text { - } 8 \text { walnuts or pecans } 20 \text { peanuts } \\
12 \text { - } 15 \text { almonds }\end{array}$ \\
\hline Legumes and nuts & $\begin{array}{l}1 / 4 \text { cup fat free refried beans or baked beans } \\
1 / 4 \text { cup kidney, black, garbanzo, pinto, soy, navy beans, split peas, or lentils }\end{array}$ \\
\hline 1 - 3 servings per day & $\begin{array}{l}\text { - } \quad \text { Aim for } 1 \text { - } 2 \text { servings of nuts or seeds and } 1 \text { - } 2 \text { servings of legumes per day. } \\
\text { - } \quad \text { Legumes are high in fiber, protein, and minerals. } \\
\text { Nuts are high in unsaturated fat, and may increase HDL without increasing LDL. }\end{array}$ \\
\hline $\begin{array}{l}\text { Fish or shellfish } \\
2 \text { - } 3 \text { servings/week }\end{array}$ & $\begin{array}{l}3 \text { ounces (about the size of a deck of cards) } \\
\text { - } \quad \text { Bake, sauté, broil, roast, grill or poach your fish. } \\
\text { Choose fatty fishes like salmon, herring, sardines, or mackerel often. The fat in fish is high in } \\
\text { omega-3 fats, so it has healthy effects on triglycerides and blood cells. }\end{array}$ \\
\hline $\begin{array}{l}\text { Poultry, if desired } \\
1 \text { - } 3 \text { servings/week }\end{array}$ & $\begin{array}{l}3 \text { ounces (about the size of a deck of cards) } \\
\text { - } \quad \text { Bake, sauté, stir fry, roast or grill the poultry you eat, and eat it without the skin. }\end{array}$ \\
\hline Healthy fat & $\begin{array}{ll}1 \text { tsp. olive or canola oil } & 2 \text { tsp light margarine } \\
1 \text { Tbsp of regular salad dressing } & 2 \text { Tbsp of light salad dressing, made with oil } 1 \text { tsp regular mayonnaise } \\
1 / 8 \text { of an avocado } & \\
5 \text { olives }\end{array}$ \\
\hline & $\begin{array}{l}\text { - These fats are mostly unsaturated and contain little or no trans fat, so they will not increase LDL } \\
\text { cholesterol levels. } \\
\text { - } \quad \text { All fats are a concentrated source of calories, so try to keep the servings small. }\end{array}$ \\
\hline Alcohol & $\begin{array}{l}\text { No more than one drink per day for women or two drinks per day for men. } \\
\text { One drink equals one } 12 \text { ounce beer, } 4 \text { ounces of wine, or } 1.5 \text { ounces liquor (whiskey, vodka, brandy, etc). } \\
\text { - } \quad \text { People with high blood pressure or high triglycerides, or those taking certain medicines may be } \\
\text { advised to avoid all alcohol. Ask your doctor to be sure. }\end{array}$ \\
\hline
\end{tabular}

Limit egg yolks to 4 per week. Egg whites can be eaten in unlimited amounts. Limit your sweets-use fruit as your dessert. Lean red meats (beef, pork, lamb and veal) can be eaten 3 - 4 times per month. Indicates foods high in sodium; these foods should be limited, especially for those with high blood pressure.

in a heart healthy Mediterranean diet.

Getting enough physical activity is very important. Start with $30-60$ minutes of moderate exercise 5 times a week. Moderate exercise includes activities like walking, biking, or swimming.

Weight Control-while eating higher amounts of unsaturated fat in the Mediterranean diet can be heart healthy, larger portion sizes may lead to increased calorie intake and weight gain. If you are trying to lose weight, choose fewer servings from each food group, and make sure your serving sizes match those listed [11].

Limit egg yolks to 4 per week. Egg whites can be eaten in unlimited amounts. Limit your sweets-use fruit as your dessert. 
Lean red meats (beef, pork, lamb and veal) can be eaten 3 - 4 times per month.

- Indicates foods high in sodium; these foods should be limited, especially for those with high blood pressure [11].

\section{Acknowledgements}

I would like to thank and dedicate this research to my deceased mother: Dr. Shkurte SAdemaj-Gashi "We know to eat, but do we know how to feed" by Erza Voca Mulaj!

\section{References}

[1] Nutrition (2007) World Health Organization. http://www.who.int/nutrition/en/

[2] Contento, I. (2007) Nutrition Education: Linking Theory, Research and Practice. Jones and Bartlett Publishers, Sudbury.

[3] Check What You Eat Everyday (2005) Nutrition Analysis Tools and Systems. http://nat.crgq.com/mainnat.html

[4] Shepherd, R. (1999) Social Determinants of Food Choice. Proceedings of the Nutrition Society, 58, 807-812. http://dx.doi.org/10.1017/S0029665199001093

[5] Oenema, A. and Brug, J. (2003) Exploring the Occurrence and Nature of Comparison of One’s Own Perceived Dietary Fat Intake to That of Self-Selected Others. Appetite, 41, 259-264. http://dx.doi.org/10.1016/S0195-6663(03)00103-X

[6] Dibsdall, L.A., Lambert, N., Bobbin, R.F. and Frewer, L.J. (2003) Low-Income Consumers’ Attitudes and Behaviour towards Access, Availability and Motivation to Eat Fruits and Vegetables. Public Health Nutrition, 6, 159-168. http://dx.doi.org/10.1079/PHN2002412

[7] Abood, D., Black, D. and Birnbaum, R. (2004) Nutrition Education Intervention for College Female Athletes. Journal of Nutrition Education \& Behavior, 36, 135-139. http://dx.doi.org/10.1016/S1499-4046(06)60150-4

[8] Anderson, A.S., Cox, D.N., McKellar, S., Reynolds, J., Lean, M.E.J. and Mela, D.J. (1998) Take Five, a Nutrition Education Intervention to Increase Fruit and Vegetable Intakes: Impact on Attitudes towards Dietary Change. British Journal of Nutrition, 80, 133-140. http://dx.doi.org/10.1017/S0007114598001032

[9] Abood, D., Black, D. and Feral, D. (2003) Nutrition Education Worksite Intervention for University Staff: Application of the Health Belief Model. Journal of Nutrition Education \& Behavior, 35, 260-267. http://dx.doi.org/10.1016/S1499-4046(06)60057-2

[10] FDA’s Plan to Tackle U.S. Obesity (2004) U.S. Food and Drug Administration. http://www.fda.gov/oc/opacom/hottopics/obesity_plan.htm

[11] Nestle, M. (2013) Food Politics: How the Food Industry Influences Nutrition and Health. Vol. 3, University of California Press.

[12] Kearney, M., Gibney, M.J., Martinez, J.A., de Almeida, M.D.V., Friebe, D., Zunft, H.J.F., Widhalm, K. and Kearney, J.M. (1997) Perceived Need to Alter Eating Habits among Representative Samples of Adults from All of the European Union. European Journal of Clinical Nutrition, 51, S30-S35.

[13] Frazao, E. and Allshouse, J. (2003) Strategies for Intervention: Commentary and Debate. Journal of Nutrition, 133, 844.

\section{Scientific Research Publishing}

\section{Submit or recommend next manuscript to SCIRP and we will provide best service for you:}

Accepting pre-submission inquiries through Email, Facebook, Linkedin, Twitter, etc

A wide selection of journals (inclusive of 9 subjects, more than 200 journals)

Providing a 24-hour high-quality service

User-friendly online submission system

Fair and swift peer-review system

Efficient typesetting and proofreading procedure

Display of the result of downloads and visits, as well as the number of cited articles

Maximum dissemination of your research work

Submit your manuscript at: http://papersubmission.scirp.org/ 